\title{
The significance of nitrogen fixation to new production during early summer in the Baltic Sea
}

\author{
U. Ohlendieck ${ }^{1}$, K. Gundersen ${ }^{2, *}$, M. Meyerhöfer ${ }^{1}$, P. Fritsche ${ }^{1}$, K. Nachtigall ${ }^{1}$, and B. Bergmann ${ }^{2}$ \\ ${ }^{1}$ Leibniz Institut für Meereswissenschaften, Düsternbrooker Weg 20, 24105 Kiel, Germany \\ ${ }^{2}$ Department of Botany, Stockholm University, Lilla Frescativägen 5, 10691 Stockholm, Sweden \\ "now at: Department of Marine Sience, University of Southern Mississippi, 1020 Balch Blvd., Stennis Space Center, MS \\ 39529, USA
}

Received: 8 May 2006 - Published in Biogeosciences Discuss.: 9 August 2006

Revised: 13 December 2006 - Accepted: 11 January 2007 - Published: 18 January 2007

\begin{abstract}
Rates of dinitrogen $\left(\mathrm{N}_{2}\right)$ fixation and primary production were measured during two 9 day transect cruises in the Baltic proper in June-July of 1998 and 1999. Assuming that the early phase of the bloom of cyanobacteria lasted a month, total rates of $\mathrm{N}_{2}$ fixation contributed $15 \mathrm{mmol} \mathrm{N} \mathrm{m}^{-2}$ (1998) and $33 \mathrm{mmol} \mathrm{N} \mathrm{m}^{-2}$ (1999) to new production (sensu Dugdale and Goering, 1967). This constitutes 12-26\% more new $\mathrm{N}$ than other annual estimates (mid July-mid October) from the same region. The between-station variability observed in both total $\mathrm{N}_{2}$ fixation and primary productivity greatly emphasizes the need for multiple stations and seasonal sampling strategies in biogeochemical studies of the Baltic Sea. The majority of new $\mathrm{N}$ from $\mathrm{N}_{2}$ fixation was contributed by filamentous cyanobacteria. On average, cyanobacterial cells $>20 \mu \mathrm{m}$ were able to supply a major part of their $\mathrm{N}$ requirements for growth by $\mathrm{N}_{2}$ fixation in both 1998 (73\%) and $1999(81 \%)$. The between-station variability was high however, and ranged from $28-150 \%$ of $\mathrm{N}$ needed to meet the rate of $\mathrm{C}$ incorporation by primary production. The molar $\mathrm{C}: \mathrm{N}$ rate incorporation ratio $\left(\mathrm{C}: \mathrm{N}_{\mathrm{RATE}}\right)$ in filamentous cyanobacterial cells was variable (range 7-28) and the average almost twice as high as the Redfield ratio (6.6) in both years. Since the molar C:N mass ratio (C:NMASS) in filamentous cyanobacterial cells was generally lower than $\mathrm{C}: \mathrm{N}_{\mathrm{RATE}}$ at a number of stations, we suggest that the diazotrophs incorporated excess $\mathrm{C}$ on a short term basis (carbohydrate ballasting and buoyancy regulation), released nitrogen or utilized other regenerated sources of $\mathrm{N}$ nutrients. Measured rates of total $\mathrm{N}_{2}$ fixation contributed only a minor fraction of 13\% (range 4-24) in 1998 and 18\% (range 2-45) in 1999 to the amount of $\mathrm{N}$ needed for the community primary production. An average of 9 and $15 \%$ of total $\mathrm{N}_{2}$ fixation was found in cells $<5 \mu \mathrm{m}$. Since cells $<5 \mu \mathrm{m}$ did not show any detectable rates of $\mathrm{N}_{2}$ fixation, the ${ }^{15} \mathrm{~N}$-enrichment
\end{abstract}

Correspondence to: U. Ohlendieck

(ute.ohlendieck@t-online.de) could be attributed to regenerated incorporation of dissolved organic $\mathrm{N}(\mathrm{DON})$ and ammonium generated from larger diazotroph cyanobacteria. Therefore, $\mathrm{N}$ excretion from filamentous cyanobacteria may significantly contribute to the pool of regenerated nutrients used by the non-diazotroph community in summer. Higher average concentrations of regenerated $\mathrm{N}$ (ammonium) coincided with higher rates of $\mathrm{N}_{2}$ fixation found during the 1999 transect and a higher level of ${ }^{15} \mathrm{~N}$-enrichment in cells $<5 \mu \mathrm{m}$. A variable but significant fraction of total $\mathrm{N}_{2}$ fixation (1-10\%) could be attributed to diazotrophy in cells between $5-20 \mu \mathrm{m}$.

\section{Introduction}

Surface blooms of filamentous diazotrophic cyanobacteria are well documented and a recurring phenomenon in the Baltic Sea in summer (cf. Leppänen et al., 1988). Due to their ability to fix $\mathrm{N}_{2}$, diazotroph cyanobacteria may contribute significantly to the input of new $\mathrm{N}$ to the Baltic Sea ecosystem. The contribution of this source of new $\mathrm{N}$ has been subject of a number of investigations (e.g. Rinne et al., 1978; Leppänen et al., 1988; Rahm et al., 2000; Larsson et al., 2001; Wasmund et al., 2001). Our current knowledge may suggest large-scale regional differences in the abundance of the most common filamentous cyanobacteria in the Baltic Sea, Aphanizomenon sp. and Nodularia sp. (Kahru et al., 1994; Wasmund, 1997). During peak abundance in summer, maximum biomass of the filamentous cyanobacteria can be found in the southern and eastern parts of the Baltic proper (Niemistö et al., 1989). Although the filamentous cyanobacteria rarely dominate the autotroph community, conspicuous surface accumulations of the buoyant diazotrophs may congregate in wind and current driven rows or patches in coastal and offshore waters of the Baltic Sea (Niemistö et al., 1989; Walsby et al., 1995). Larsson et al. (2001) clearly demonstrated the great extent of inter-annual variability in timing

Published by Copernicus GmbH on behalf of the European Geosciences Union. 


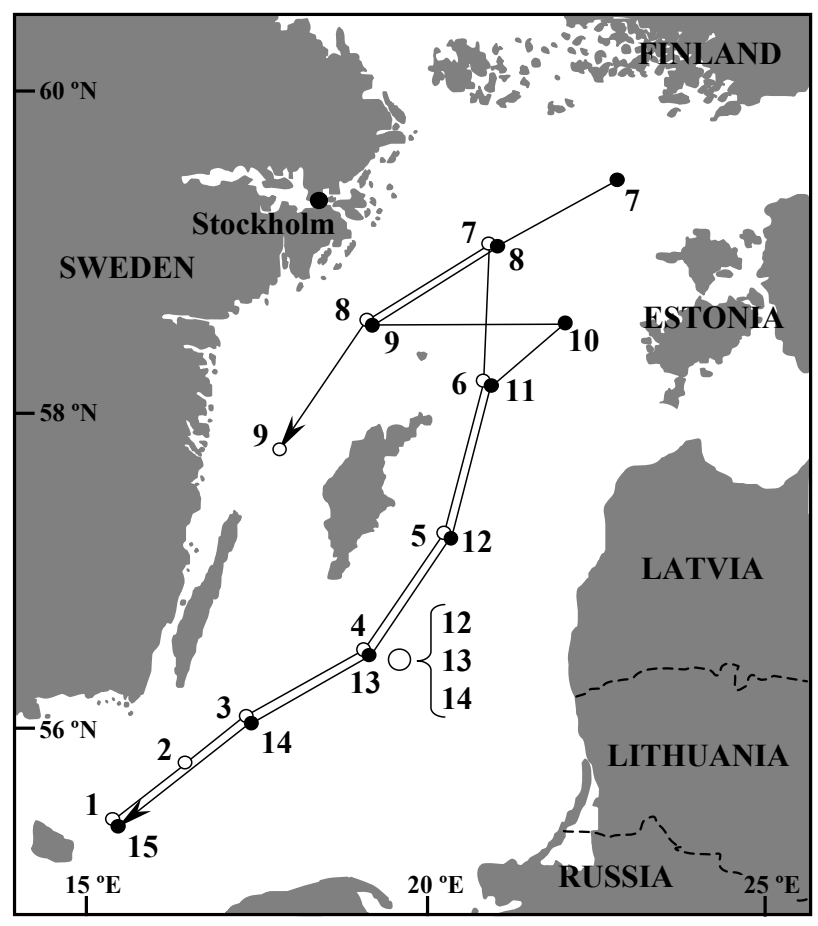

Fig. 1. Map of the Baltic Sea showing the cruise tracks in 1998 (open circles, S-N) and 1999 (closed circles, N-S). Location of the drift station experiment in 1998 (larger open circle; stations 12-14) is also shown.

and total abundance of filamentous cyanobacteria at an offshore station in the Baltic Sea. A similar spatial and temporal variability in measured rates of $\mathrm{N}_{2}$ fixation during the growth season of diazotrophic cyanobacteria has been found by Ohlendieck et al. (2000) and Wasmund et al. (2001).

The earliest estimates of $\mathrm{N}_{2}$ fixation in the Baltic Sea were based on the acetylene-reduction method. Plankton samples were routinely concentrated in net-tows or by a screen from natural seawater. Due to this pre-treatment of the samples, the enrichment method may have excluded or even physiologically disturbed certain plankton groups and hence, underestimated total rates of $\mathrm{N}_{2}$ fixation to the Baltic Sea. More recent studies however, have applied the sensitive ${ }^{15} \mathrm{~N}$ tracer method using natural water samples to measure $\mathrm{N}_{2}$ fixation directly (Montoya et al., 1996; Ohlendieck et al., 2000; Wasmund et al., 2001). The ${ }^{15} \mathrm{~N}$ method opened the possibility to investigate the significance of new (nitrate, nitrite and $\mathrm{N}_{2}$ ) and regenerated (ammonium) $\mathrm{N}$ incorporated into the autotroph community of Baltic Sea phytoplankton (e.g. Sörensson and Sahlsten, 1987; Sahlsten and Sörensson, 1989). A number of studies have also used the ${ }^{15} \mathrm{~N}$ method to monitor the direct transfer of newly fixed $\mathrm{N}$ into the planktonic foodweb (Paerl, 1984; Glibert and Bronk, 1994; Ohlendieck et al., 2000).

Historically, decay and cell lysis of cyanobacteria have been viewed as a significant source of regenerated N (Lin- dahl et al., 1980; Schultz and Kaiser, 1986) and high concentrations of dissolved organic nutrients have been found during and immediately after blooms of Baltic Sea cyanobacteria (Gundersen, 1981; Kuparinen et al., 1984). However, Ohlendieck et al. (2000) found that actively growing diazotroph filamentous cyanobacteria transferred DON to the picoplankton community during the early stages of a summer bloom. A similar observation was made by Gallon et al. (2002), who attributed the discrepancy between the acetylene reduction method (gross $\mathrm{N}_{2}$ fixation) and the ${ }^{15} \mathrm{~N}$-tracer method (net $\mathrm{N}_{2}$ fixation) in filamentous cyanobacteria collected over several diel cycles to be DON excretion by the diazotrophs. Exoenzymes are instrumental in the regenerative process of dissolved organic matter and have been found in association with filamentous cyanobacteria in the Baltic Sea (Stoecker et al., 2005). Therefore, filamentous cyanobacteria may not only be a source of DON for the non-diazotrophs, but also serve as an active centre of organic nutrient regeneration to the plankton community. Until recently, filamentous cyanobacteria were considered the only diazotroph organisms that contributed significantly to new production by $\mathrm{N}_{2}$ fixation in the Baltic Sea. Nitrogen fixation by single cell cyanobacteria (Wasmund et al., 2001; Zehr et al., 2001; Montoya et al., 2004) however, may also be of importance and represents another source of new $\mathrm{N}$ to the pelagic foodweb.

The aim of this study was to assess the significance of $\mathrm{N}_{2}$ fixation to new production during the early stages of a cyanobacterial bloom. During two successive years, rates of $\mathrm{N}_{2}$ fixation and primary production were monitored in early summer at 9 stations along a N-S transect covering the major parts of the Baltic proper. By exclusion filtration of natural seawater prior to and after in situ incubations, we identified the significance of single cell diazotrophs and the magnitude of DON excretion by filamentous cyanobacteria incorporated by organisms $<5 \mu \mathrm{m}$. By applying known molar carbon to nitrogen incorporation ratios (C: $\mathrm{N}_{\mathrm{RATE}}$ ) for filamentous cyanobacteria, we estimated the significance of $\mathrm{N}_{2}$ fixation contributing to new $\mathrm{N}$ growth in filamentous cyanobacteria.

\section{Materials and methods}

CTD profiles and seawater samples were collected at designated stations (Fig. 1) on two transect cruises in the Central Baltic Sea in 1998 (23 June-1 July) and 1999 (21 June29 June). During a drift station experiment (see Gallon et al., 2001), three day-stations were kept during 5 additional days in 1998 (6 July-11 July; drift stations 12-14; Fig. 1). Physical parameters were measured using a Neil-Brown unit equipped with conductivity, temperature and density (CTD) sensors. Only temperature profiles are reported here. Seawater was collected at pre-determined depths using Hydrobios water samplers attached to the CTD unit (1998) or the same water samplers attached to a hydro-wire (1999). Upon re- 
trieval on deck, a small quantity of water (approx. $150 \mathrm{~mL}$ ) was collected immediately from each water sampler for nutrient analysis (see below). The majority of the water sample from each depth was transferred to a $20 \mathrm{~L}$ canister. Each canister was gently homogenized by inverting it a couple of times prior to sub-sampling. Sub-sample aliquots were immediately dispensed into parallel incubation bottles for in situ $\mathrm{N}_{2}$ fixation and primary production incubations using the ${ }^{15} \mathrm{~N}$ and ${ }^{14} \mathrm{C}$ tracer methods (see below) and for HPLC pigment analysis (see below). The incubation bottles were deployed at ambient depths on a free-floating array from 07:00-19:00 h (1998 transect) or 06:00-18:00 h (1999 transect). During the drift station experiment in 1998 (Fig. 1), incubations lasted from 04:00-16:00 $\mathrm{h}$ daytime $\left(\mathrm{N}_{2}\right.$ fixation and primary production) and 16:00-04:00 h at night $\left(\mathrm{N}_{2}\right.$ fixation). At noon each day, samples were also collected for particulate organic carbon (POC), particulate nitrogen (PN) and particulate total phosphorus (PTP) analysis (see below).

\subsection{Nutrient analysis}

Nutrient samples were collected in the morning and afternoon at each station visited. The nutrient samples were stored at $4^{\circ} \mathrm{C}$ and analysed daily (typically within $4 \mathrm{~h}$ of sampling) using an onboard auto-analyser. Dissolved inorganic nitrogen (DIN; nitrate, nitrite, ammonium) and soluble reactive phosphate (SRP) were determined according to the methods described by Grasshoff et al. (1983). A daily average using the morning and afternoon data was calculated for each station visited.

\section{$2.2 \mathrm{~N}_{2}$ fixation}

Sample aliquots were collected in replicates of 0.5 or $1 \mathrm{~L}$ polycarbonate bottles filled to the brim and sealed with a butyl rubber septum cap. Great care was taken to avoid air-bubbles inside the sealed incubation bottles. A gas-tight syringe was used to inject ${ }^{15} \mathrm{~N}$-labelled dinitrogen $\left(\mathrm{N}_{2}\right)$ gas (99 atom $\%{ }^{15} \mathrm{~N}$, Campro Scientific) and excess water was allowed to bleed out through a second injection needle to equalize pressure. Final ${ }^{15} \mathrm{~N}_{2}$ enrichments ranged between 5.4-6.1 atom $\% \mathrm{~N}$ depending on the physical parameters of the sample water (Weiss, 1970). Each incubation was terminated by collecting the cells on pre-combusted $\left(450^{\circ} \mathrm{C}, 6 \mathrm{~h}\right)$ $25 \mathrm{~mm}$ Whatman GF/F filters using low vacuum $(<100 \mathrm{~mm}$ $\mathrm{Hg}$ ) filtration. At all stations in both years, one whole seawater sample from each depth was collected on a GF/F filter (total $\mathrm{N}_{2}$ fixation) and one sample was screened through a $5 \mu \mathrm{m}$ membrane filter and cells $<5 \mu \mathrm{m}$ were collected on a GF/F filter upon terminating the incubation. In another set of samples (see Table 2 for details) cells $>20 \mu \mathrm{m}$ were collected on a Nytex screen and transferred to a GF/F filter using GF/F filtered seawater. A number of samples were also screened prior to deployment and cells $<5 \mu \mathrm{m}$ were incubated separately as a control to test for $\mathrm{N}_{2}$ fixed by this fraction, during the 1998 transect (all stations) and the 1999 transect (stations 9, 11, 13 and 15). During the 1998 transect (stations 6-9) cells $<20 \mu \mathrm{m}$ were also separated prior to the in situ incubations to test for $\mathrm{N}_{2}$ fixation by smaller sized cyanobacteria. Incubations with pre-screened cells $<5 \mu \mathrm{m}$ and $<20 \mu \mathrm{m}$ were terminated and collected on separate GF/F filters. Each filter sample was wrapped in pre-combusted aluminium foil and stored at $-20^{\circ} \mathrm{C}$ until further analysis. In the laboratory, the samples were dried at $60^{\circ} \mathrm{C}$, wrapped in tin cups (Heraeus CHN cups) and packed into pellets. The ${ }^{15} \mathrm{~N}$ enrichments were analysed on a Europa Mass Spectrometer 20-20, with an ANCA-SL preparatory unit (Crewe, England, UK). The mass spectrometer was standardised with bovine serum albumin and the precision of the analytical procedure, as measured by standard deviation of the nitrogen isotope, was typically $0.04 \%$. The rate of $\mathrm{N}_{2}$ fixation was calculated according to Montoya et al. (1996).

\subsection{Primary production}

Sample water was collected in acid cleaned (10\% hydrochloric acid) $250 \mathrm{~mL}$ Erlenmeyer polycarbonate incubation bottles. Three replicate incubation bottles, a time zero and a dark bottle were collected for each depth. The primary production method was adapted to the trace-metal clean procedures outlined by Fitzwater et al. (1982). Under low light conditions ${ }^{14} \mathrm{C}$-labelled sodium bicarbonate was added to each flask at the start of the assay (final specific activity $=1.6 \mu \mathrm{g} \mathrm{C} \mathrm{nCi}^{-1}$ ) and the time zero was immediately filtered and processed. At the end of the incubation and under low light conditions, each bottle was immediately filtered onto a $25 \mathrm{~mm}$ Whatman GF/F filter. Thereby particles $>20 \mu \mathrm{m}$ were collected separately at all stations in both years. The size fraction $>20 \mu \mathrm{m}$ was collected on a Nytex screen and transferred to a $25 \mathrm{~mm}$ Whatman GF/C filter using GF/F filtered seawater. Each filter was placed in a $20 \mathrm{~mL}$ scintillation vial and added $250 \mu \mathrm{L}$ $\mathrm{HCl}(0.5 \%)$ until further processing after each cruise. In the laboratory all sample vials were uncapped and the residual ${ }^{14} \mathrm{C}$-bicarbonate was left to evaporate off the filters in a fume hood. Ultima Gold XR scintillation cocktail was added to each filter sample and the activity was counted on a Wallac 1409 Liquid Scintillation Counter using the external channel ratio method.

\subsection{HPLC pigment analysis}

Sample water aliquots of $2 \mathrm{~L}$ were filtered onto Whatman GF/F filters. Cells $>20 \mu \mathrm{m}$ were collected separately at stations 1-7 in 1998 and on all stations (except stations 9-11) in 1999. The size fraction $>20 \mu \mathrm{m}$ was collected on a Nytex screen and transferred to a $25 \mathrm{~mm}$ Whatman GF/C filter using GF/F filtered seawater. The filter samples were wrapped in aluminium foil and stored in liquid nitrogen until further analysis. Each pigment sample was placed in $2.5 \mathrm{~mL}$ (90\%) acetone and, to ensure complete extraction, each sample was 


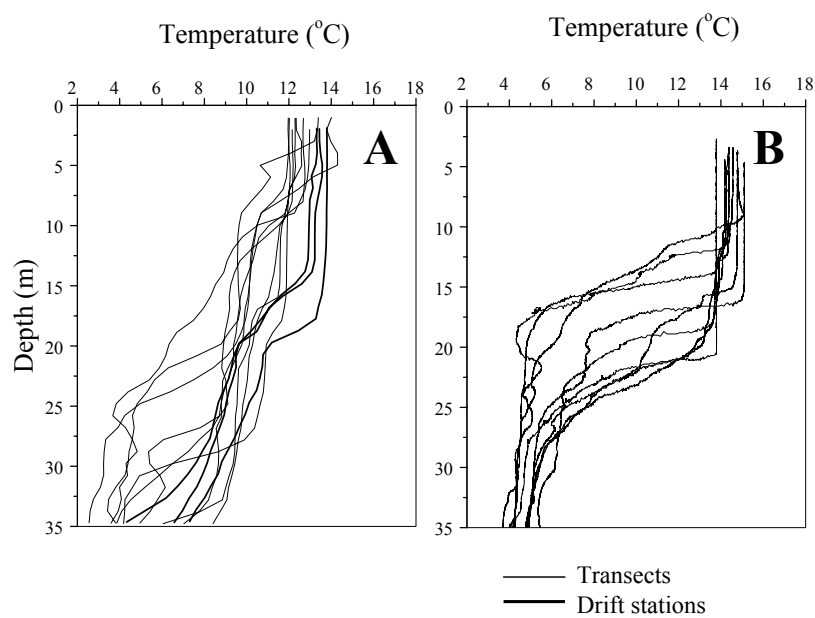

Fig. 2. Seawater temperature measured as a function of depth at the transect stations in 1998 (A) and 1999 (B). Temperature profiles at the drift stations 12-14 (thicker lines in Fig. 2A) are also shown.

added a mixture of 2 and $4 \mathrm{~mm}$ glass beads and shaken for 5 min in a cooled Vibrogen cell mill (Buehler, Germany). Subsequently, the extracts were centrifuged $(5000 \mathrm{rpm})$ for $10 \mathrm{~min}$ at $-10^{\circ} \mathrm{C}$ and the supernatant analysed according to the method of Derenbach (1969). The entire processing and analysis was executed under low light conditions to prevent photo-oxidation of the pigments. Pigment concentrations were determined by reverse-phase high-performance liquid chromatography (RP-HPLC) according to the method of Barlow et al. (1997) using a diode array spectrophotometer (Waters) and commercially available pigment standards (Sigma Chemical Company, USA and International Agency for ${ }^{14} \mathrm{C}$ Determination, Denmark). The pigment composition from each sample was used to calculate the relative proportion of phytoplankton classes to total chlorophyll $a$ (Chl a) using the CHEMTAX program (Mackey et al., 1996). Only the fraction of total Chl $a$ associated with filamentous cyanobacteria is shown in this study. The ratio between the class specific pigment of filamentous cyanobacteria (echinenone) and Chl $a$ was established from natural samples of the filamentous diazotrophs collected specifically for this purpose during the two cruises.

\subsection{POC and PN analysis}

Sample aliquots of $0.5 \mathrm{~L}$ from each depth were filtered onto pre-combusted $\left(5 \mathrm{~h}, 500^{\circ} \mathrm{C}\right) 25 \mathrm{~mm}$ Whatman $\mathrm{GF} / \mathrm{F}$ filters, that were wrapped in pre-combusted aluminium foil and stored at $-20^{\circ} \mathrm{C}$. Particles $>20 \mu \mathrm{m}$ were collected separately at all stations in both years. A sample aliquot of $1 \mathrm{~L}$ was collected on a $20 \mu \mathrm{m}$ Nytex screen and the retained particles transferred to a $25 \mathrm{~mm}$ Whatman GF/C filter. Prior to analysis, the filters were dried at $65^{\circ} \mathrm{C}$, fumigated by concentrated $\mathrm{HCl}$, dried again and packed in tin capsules. The POC and
PN content was analysed using a Control Equipment Corporation 240-XA Elemental Analyzer (1998) or a Carlo-Erba Strumentazione Elemental Analyser (1999).

\subsection{PTP analysis}

Sample aliquots of $0.5 \mathrm{~L}$ were filtered onto $\mathrm{HCl}$ washed $25 \mathrm{~mm}$ Whatman GF/F filters. Particles $>20 \mu \mathrm{m}$ were collected separately at all stations in both years. A sample aliquot of $1 \mathrm{~L}$ was collected on a $20 \mu \mathrm{m}$ Nytex screen and the retained particles transferred to a $25 \mathrm{~mm}$ Whatman GF/C filter. Analysis of cellular P by the ashing-hydrolysis method was performed as discussed in Solorzano and Sharp (1980). The filters were soaked in phosphate-free, deionised water (particle free) and were dried prior to use. The filter-collected samples were rinsed with $0.17 \mathrm{M} \mathrm{Na}_{2} \mathrm{SO}_{4}$ and stored in acid cleaned containers at $-20^{\circ} \mathrm{C}$. Prior to analysis, the samples were thawed and $0.017 \mathrm{M} \mathrm{MgSO}_{4}$ was added before being left overnight at $95^{\circ} \mathrm{C}$. The samples were then combusted at $500^{\circ} \mathrm{C}$ for $3 \mathrm{~h}$ and the remaining $\mathrm{P}$ was extracted in $2 \mathrm{~mL}$ of $0.2 \mathrm{M} \mathrm{HCl}$ at $80^{\circ} \mathrm{C}$ for a minimum of $1 \mathrm{~h}$. The acid extraction solution was centrifuged $(30 \mathrm{~min}, 5000 \mathrm{rpm})$, and the supernatant analysed as for SRP according to Grasshoff et al. (1983).

\section{Results}

Average surface water temperature was approximately $2^{\circ} \mathrm{C}$ higher in 1999 than in 1998 (Fig. 2). The thermocline was more pronounced in 1999 and during the drift station experiment in 1998 (Fig. 2). DIN (0.1-0.2 $\mu \mathrm{M}$ ) was slightly higher in 1999 than during the 1998 transect with average concentrations of ammonium twice as high in 1999 (Fig. 3a, b). The average concentration of SRP in surface waters (0$14 \mathrm{~m})$ was uniformly low during the 1999 transect $(0.08 \mu \mathrm{M})$ (Fig. 3c, d) and slightly higher in 1998 (average of $0.2 \mu \mathrm{M}$ at the southern stations and $0.05 \mu \mathrm{M}$ at the northern stations). Due to these differences between the years, the median (geometric mean) of the molar N:P ratio (1-3) was almost twice as high during the 1999 transect. Cursory microscopy of live samples during the two cruise transects showed that Aphanizomenon sp. was the predominant filamentous cyanobacteria in surface waters at the northern stations (data not shown), whereas Nodularia sp. appeared more frequent at the southern stations.

Total Chl $a$ as a function of depth did not show any pronounced inter-annual differences (Fig. 4a). Integrated rates of total $\mathrm{N}_{2}$ fixation were a fraction of 0.71 lower at night than in daytime at the drift station (Table 1). The daytime rates of $\mathrm{N}_{2}$ fixation ( $\mathrm{NF}_{\mathrm{DAY}}$ ) measured on all transect stations in both years, were factor corrected for the night-time activity $\left(\mathrm{NF}_{\mathrm{DAY}}+\mathrm{NF}_{\mathrm{DAY}} * 0.71\right)$ to yield daily rates (Fig. $\left.4 \mathrm{~b}\right)$. Since primary production was measured from dawn to dusk, no correction factor was used for this parameter. With the 

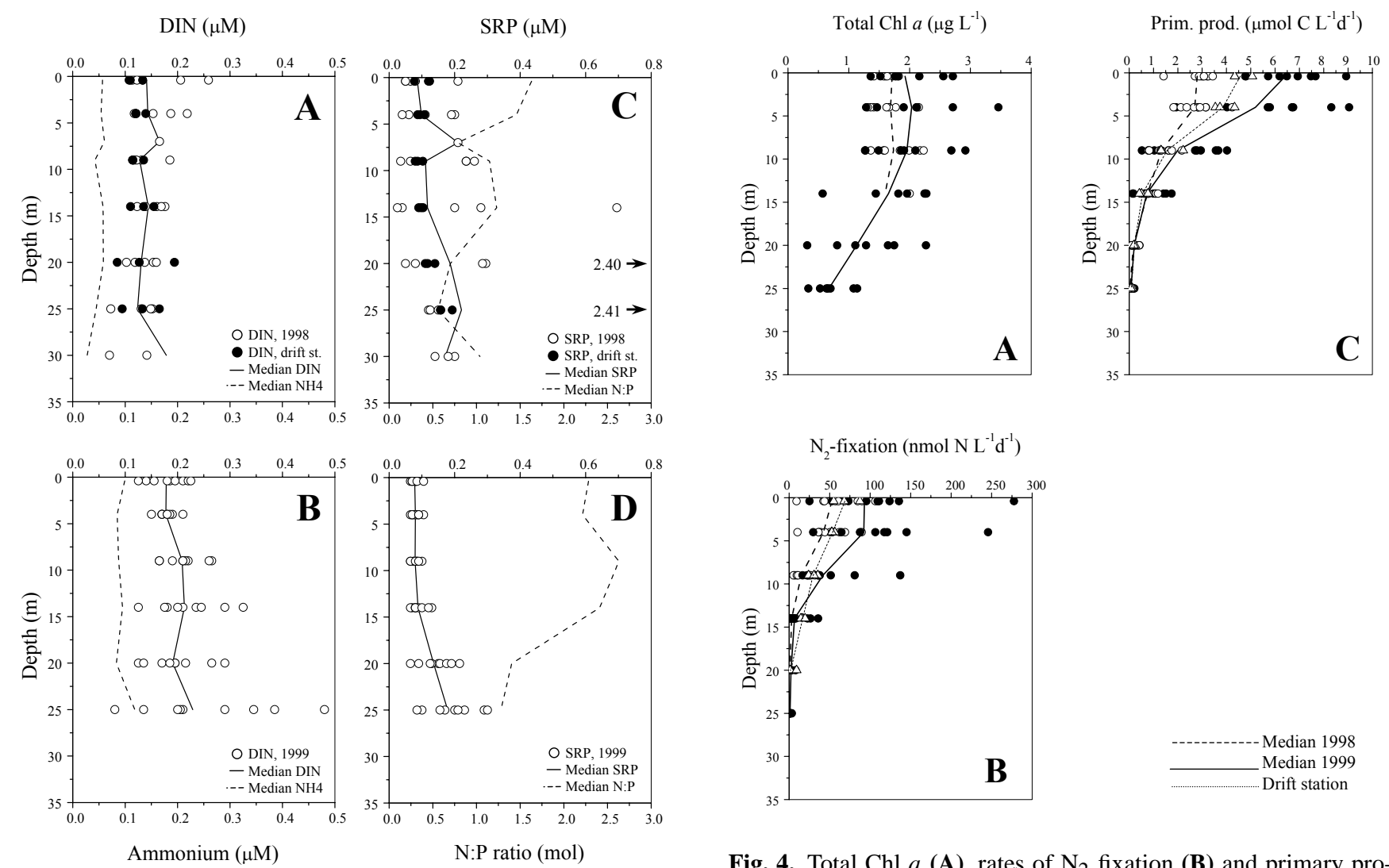

Fig. 3. DIN concentrations (open circles) as a function of depth in 1998 (A) and 1999 (B). The geometric average of DIN (whole line) and ammonium (dashed line) is shown for each cruise transect each year. SRP concentrations (open circles) as a function of depth in 1998 (C) and 1999 (D). The geometric average of SRP (whole line) and the molar N:P ratio (dashed line) is shown for each cruise in each year. Nutrient samples were also collected at the drift station casts 12-14 (whole circles). Stations 1, 2, 6 and 7 in 1998 did not have all nutrients analysed and were not included in the graph.

Table 1. Rates of $\mathrm{N}_{2}$ fixation measured in daylight (04:00-16:00 h) and at night (16:00-04:00 h) in whole seawater from the Baltic Sea in 1998. The rates from each station were integrated (0-14 m) and the $\mathrm{N}_{2}$ fixation at night was calculated as a fraction of the daytime.

\begin{tabular}{lccc}
\hline Station & $\begin{array}{c}\text { Day } \\
\mathrm{nmol} \mathrm{N} \mathrm{m}{ }^{-2} \mathrm{~h}^{-1}\end{array}$ & $\begin{array}{c}\text { Night } \\
\mathrm{nmol} \mathrm{N} \mathrm{m}{ }^{-2} \mathrm{~h}^{-1}\end{array}$ & Night:Day \\
\hline 12 & 30.34 & 21.65 & 0.71 \\
13 & 30.45 & 21.54 & 0.71 \\
\hline
\end{tabular}

exception of the drift stations, the rates of $\mathrm{N}_{2}$ fixation and primary production were twice as high in surface waters in 1999 compared to 1998 (Fig. 4b, c). Very low rates or no $\mathrm{N}_{2}$ fixation and primary production were detected below $14 \mathrm{~m}$ depth in both transects. The median average of the depth-

Fig. 4. Total Chl $a$ (A), rates of $\mathrm{N}_{2}$ fixation (B) and primary production (C) plotted as a function of depth in 1998 (open circles) and 1999 (closed circles). Where available, the geometric average at each depth was calculated for the 1998 transect cruise (dashed line) and drift station (dotted line) and the cruise transect in 1999 (solid line).

integrated rates of total $\mathrm{N}_{2}$ fixation $(0-14 \mathrm{~m})$ from each transect were $0.5 \mathrm{mmol} \mathrm{N} \mathrm{m}^{-2} \mathrm{~d}^{-1}$ in 1998 (range 0.1-0.8) and $1.0 \mathrm{mmol} \mathrm{N} \mathrm{m}^{-2} \mathrm{~d}^{-1}$ in 1999 (range 0.3-2.7). The median average of the depth-integrated rates of total primary production from each transect were $32.3 \mathrm{mmol} \mathrm{C} \mathrm{m}^{-2} \mathrm{~d}^{-1}$ in 1998 (range 20.4-40.9) and $57.9 \mathrm{mmol} \mathrm{C} \mathrm{m}^{-2} \mathrm{~d}^{-1}$ in 1999 (range 25.9-85.2).

Rates of ${ }^{15} \mathrm{~N}$ enrichment in cells $<5 \mu \mathrm{m}$ (separated after incubation) were plotted as a linear function of total $\mathrm{N}_{2}$ fixation for both transects in 1998 and 1999 (Fig. 5) and the average fraction of ${ }^{15} \mathrm{~N}$ enrichment in cells $<5 \mu \mathrm{m}$ (the slope) was 0.09 in 1998 and 0.15 in 1999 . Cells $<5 \mu \mathrm{m}$ (separated prior to incubation) showed no detectable uptake. Cells $<20 \mu \mathrm{m}$ (separated prior to incubation) at stations 6-9 in 1998 showed low rates of $\mathrm{N}_{2}$ fixation (median fraction 0.05 of total $\mathrm{N}_{2}$ fixation) but the ratios were variable (range 0.010.1 ) between stations (Table 2).

Diazotroph specific Chl $a$ was plotted as a linear function of Chl $a>20 \mu \mathrm{m}$ (Fig. 6). The fraction of diazotrophy in cells $>20 \mu \mathrm{m}$ ranged between $0.92-0.88$ of the total rate of $\mathrm{N}_{2}$ fixation in surface waters in 1998 , and was 0.48 of 
Table 2. Integrated rates of $\mathrm{N}_{2}$ fixation $(0-14 \mathrm{~m})$ in whole seawater and cells $<20 \mu \mathrm{m}$ in the Baltic Sea in 1998 . Cells $<20 \mu \mathrm{m}$ were separated prior to the in situ daytime incubations and the rates of $\mathrm{N}_{2}$ fixation in cells $<20 \mu \mathrm{m}$ were also calculated as a fraction of the total rate.

\begin{tabular}{lccc}
\hline Station & $\begin{array}{c}\text { Total } \mathrm{N}_{2} \text { fixation } \\
\mu \mathrm{mol} \mathrm{N} \mathrm{m}^{-2} \mathrm{~h}^{-1}\end{array}$ & $\begin{array}{c}\mathrm{N}_{2} \text { fixation }<20 \mu \mathrm{m} \\
\mu \mathrm{mol} \mathrm{N} \mathrm{m}^{-2} \mathrm{~h}^{-1}\end{array}$ & $\begin{array}{c}\text { Fraction }<20 \mu \mathrm{m} \\
\text { ratio }\end{array}$ \\
\hline 6 & 27.15 & 0.18 & 0.01 \\
7 & 22.51 & 2.06 & 0.09 \\
${ }^{*} 8$ & 18.13 & 1.79 & 0.10 \\
9 & 38.21 & 3.89 & 0.10 \\
\hline
\end{tabular}

${ }^{(*)}=0-9 \mathrm{~m}$ integration (sample at $14 \mathrm{~m}$ depth missing)

Table 3. Rates of $\mathrm{N}_{2}$ fixation measured in cells larger and smaller than $20 \mu \mathrm{m}$ (separated after incubation) in the Baltic Sea in 1998 (stations 6-9) and 1999 (stations 7-15). The rates from each station were averaged per depth and the rate of $\mathrm{N}_{2}$ fixation in cells $>20 \mu \mathrm{m}$ was calculated as a fraction of the total rate.

\begin{tabular}{lccc}
\hline $\begin{array}{l}\text { Depth } \\
\mathrm{m}\end{array}$ & $\begin{array}{c}\text { Total } \mathrm{N}_{2} \text { fixation } \\
\mathrm{nmol} \mathrm{N} \mathrm{L} \mathrm{L}^{-1} \text { (range) }\end{array}$ & $\begin{array}{c}\mathrm{N}_{2} \text { fixation }>20 \mu \mathrm{m} \\
\mathrm{nmol} \mathrm{N} \mathrm{L} \mathrm{L}^{-1}(\text { range) }\end{array}$ & $\begin{array}{c}\text { Fraction }>20 \mu \mathrm{m} \\
\text { ratio (range) }\end{array}$ \\
\hline $1998:$ & & & \\
0 & $3.08(2.06-5.18)$ & $2.86(1.74-4.54)$ & $0.92(0.84-1.00)$ \\
4 & $2.68(2.14-4.36)$ & $2.38(1.70-3.80)$ & $0.89(0.82-0.97)$ \\
9 & $1.16(0.54-1.54)$ & $1.00(0.48-1.28)$ & $0.88(0.81-1.00)$ \\
14 & $0.22(0.12-0.40)$ & $0.12(0.04-0.26)$ & $0.48(0.29-0.65)$ \\
& & & \\
$1999:$ & & $4.28(1.02-10.92)$ & $0.81(0.69-0.99)$ \\
4 & $5.42(1.22-13.52)$ & $4.50(1.22-10.12)$ & $0.85(0.70-1.00)$ \\
\hline
\end{tabular}

the total at $14 \mathrm{~m}$ depth (Table 3 ). The fraction of $\mathrm{N}_{2}$ fixation in cells $>20 \mu \mathrm{m}$ was $0.81-0.85$ in surface waters in 1999 (Table 3). The average fractions of $\mathrm{N}_{2}$ fixation in cells $>20 \mu \mathrm{m}$ were used to calculate the integrated rate of $\mathrm{N}_{2}$ fixation in cells $>20 \mu \mathrm{m}$ at each station of both transects. In 1999, the depths without data were substituted with the results from the 1998 transect (Table 3). The fraction of primary production in cells $>20 \mu \mathrm{m}$ varied widely between stations in each year (Table 4) but the median value in 1998 (0.17) was similar to the median calculated in 1999 (0.16). The median fractions of integrated Chl $a$ and PTP in particles $>20 \mu \mathrm{m}$ were similar in both years and approximately one fifth of the total (Table 4). The fractions of integrated POC and PN in particles $>20 \mu \mathrm{m}$ (relative to total amount) were slightly higher and approximately one third of the total (Table 4). Both the molar elemental ratios of $\mathrm{C}: \mathrm{N}$ in particles $>20 \mu \mathrm{m}\left(\mathrm{C}: \mathrm{N}_{\text {MASS }}>20 \mu \mathrm{m}\right)$ and total integrated C:NMAS were lower in 1999 than in 1998 (Table 4). The median of total C:P $\mathrm{P}_{\text {MASS }}$ was higher in 1999 and the integrated $\mathrm{C}: \mathrm{P}$ in particles $>20 \mu \mathrm{m}\left(\mathrm{C}: \mathrm{P}_{\text {MASS }}>20 \mu \mathrm{m}\right)$ varied little between the two years, but was higher than total C:PMASS (Table 4). The median of the total $\mathrm{C}: \mathrm{N}$ incorporation ratio was more than 5 times higher than the molar $\mathrm{C}: \mathrm{N}$ incorporation in cells
$>20 \mu \mathrm{m}\left(\mathrm{C}: \mathrm{N}_{\mathrm{RATE}}>20 \mu \mathrm{m}\right)$ and both size fractions were similar between the years (Table 4 ). The calculated C:N $\mathrm{N}_{\text {RATE }}$ in cells $>20 \mu \mathrm{m}$ increased as a function of daily integrated PAR (Fig. 7).

\section{Discussion}

\subsection{Early blooms of diazotrophic cyanobacteria}

We found a striking difference in surface water hydrography between the two summer transects investigated in 1998 and 1999. Surface waters during the 1999 transect were warmer and had a variable, but more pronounced thermocline than in 1998. This difference appeared to be reflected in the overall plankton community production. Given the great variability between stations in each year (Fig. 3) there was a general trend towards higher rates of both $\mathrm{N}_{2}$ fixation and primary production in surface waters in 1999. This was also evident in the median rates of total $\mathrm{N}_{2}$ fixation and primary production that were a factor of 2 higher during the 1999 transect. The hydrography at the drift stations visited 5 days after the 1998 transect (st. 12-14) were characterized by a stronger thermocline and slightly warmer surface wa- 
Table 4. Integrated mass and primary production in cells $>20 \mu \mathrm{m}$ calculated as the fraction of the total, during two transect cruises (1998, 1999 ) in the Baltic Sea. The molar ratios of integrated mass and elemental incorporation in two size fractions (total mass and particles $>20 \mu \mathrm{m})$ were also calculated.

\begin{tabular}{|c|c|c|}
\hline & $\begin{array}{c}1998 \\
\text { median (range) }\end{array}$ & $\begin{array}{c}1999 \\
\text { median (range) }\end{array}$ \\
\hline \multicolumn{3}{|c|}{ Fraction $>20 \mu \mathrm{m}(0-14 \mathrm{~m})$ : } \\
\hline Primary production & $0.17(0.13-0.25)$ & $0.16(0.06-0.27)$ \\
\hline Chl $a$ & $0.16(0.07-0.27)$ & $0.24(0.12-0.46)$ \\
\hline POC & $0.37(0.31-0.43)$ & $0.27(0.18-0.58)$ \\
\hline $\mathrm{PN}$ & $0.34(0.31-0.42)$ & $0.29(0.18-0.68)$ \\
\hline PTP & $0.18(0.12-0.31)$ & $0.20(0.10-0.36)$ \\
\hline \multicolumn{3}{|c|}{ Integrated molar ratios $(0-14 \mathrm{~m})$ : } \\
\hline $\mathrm{C}: \mathrm{N}_{\text {MASS }}>20 \mu \mathrm{m}$ & $10.1(7.8-12.0)$ & $6.8(5.8-7.8)$ \\
\hline $\mathrm{C}: \mathrm{N}_{\text {MASS }}$ total & $9.2(8.6-10.2)$ & $7.4(7.1-7.9)$ \\
\hline $\mathrm{C}: \mathrm{P}_{\mathrm{MASS}}>20 \mu \mathrm{m}$ & $204.7(124.5-285.3)$ & $195.9(127.3-355.1)$ \\
\hline $\mathrm{C}: \mathrm{P}_{\text {MASS }}$ total & $98.4(84.2-113.5)$ & $145.3(123.8-166.5)$ \\
\hline $\mathrm{C}: \mathrm{N}_{\mathrm{RATE}}>20 \mu \mathrm{m}$ & $12.1(8.2-27.7)$ & $11.6(6.5-17.6)$ \\
\hline $\mathrm{C}: \mathrm{N}_{\mathrm{RATE}}$ total & $65.0(36.9-185.0)$ & $60.0(22.3-249.6)$ \\
\hline
\end{tabular}

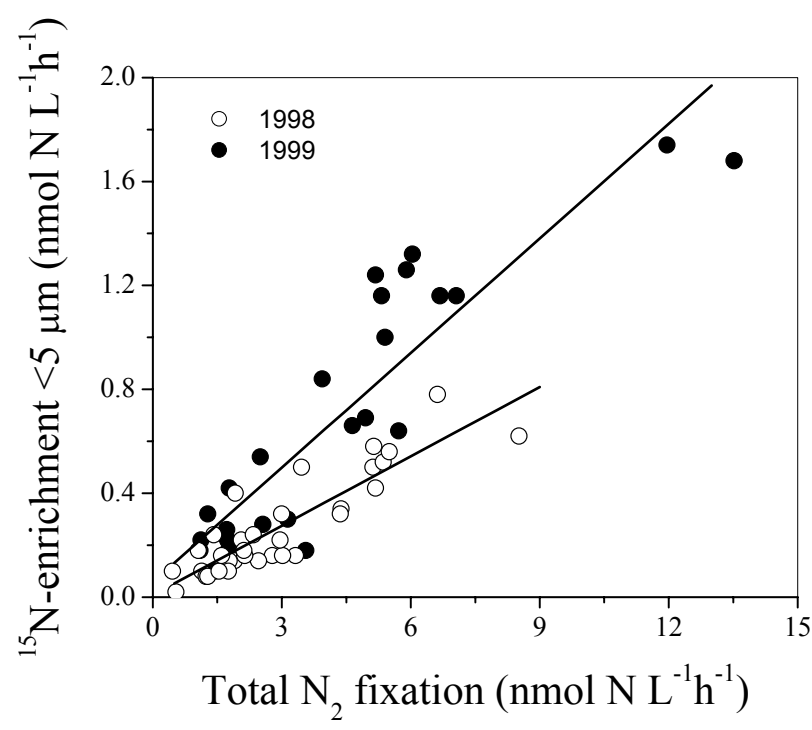

Fig. 5. Rates of ${ }^{15} \mathrm{~N}$ enrichment in cells $<5 \mu \mathrm{m}$ (screened after incubation) as a function of total $\mathrm{N}_{2}$ fixation measured from water samples at the transect stations 1-9 and at the drift station experiment (stations 12-14) in 1998 (open circles) and from the transect stations 7-15 in 1999 (closed circles). Solid lines shows the linear regression in 1998; $\mathrm{y}=0.089( \pm 0.009) \cdot \mathrm{x}+0.008( \pm 0.030), \mathrm{n}=33, \mathrm{R}=0.881, \mathrm{P}<0.0001$; and in 1999; $\mathrm{y}=0.147( \pm 0.014) \cdot \mathrm{x}+0.058( \pm 0.075), \mathrm{n}=26, \mathrm{R}=0.904$, $\mathrm{P}<0.0001$. Rates of ${ }^{15} \mathrm{~N}$ enrichment in cells $<5 \mu \mathrm{m}$ at stations $1-2$ in 1998 were below detection and not included in this figure.

ters than observed earlier in the cruise that year. The higher rates of $\mathrm{N}_{2}$ fixation and primary production at the drift sta-

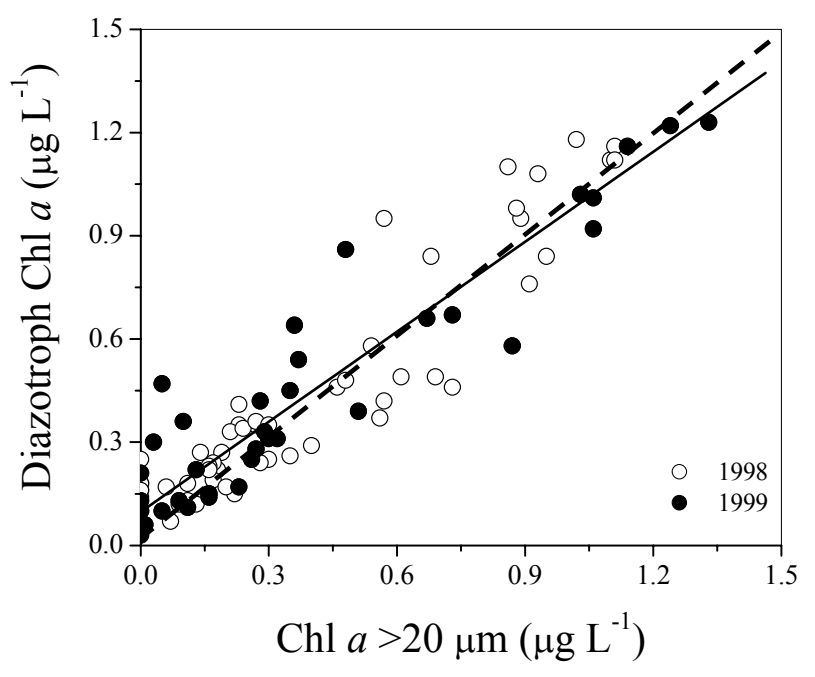

Fig. 6. Diazotroph Chl $a$ plotted as a function of Chl $a>20 \mu \mathrm{m}$ in samples collected from the cruise transects in 1998 (open circles) and 1999 (closed circles). Dashed line is the 1:1 relationship and the solid line shows the linear regression of both cruises combined; $\mathrm{y}=0.872( \pm 0.036) \cdot \mathrm{x}+0.098( \pm 0.019), \mathrm{n}=90, \mathrm{R}=0.933, \mathrm{P}<0.0001$.

tion (Fig. 3b, c) may suggest that, once in place, the plankton community was able to respond quickly to changes in hydrography and the strengthening of the thermocline. Integrated estimates by Wasmund et al. (2001) for the central Baltic Sea in 1997-1998 showed that $75 \mathrm{mmol} \mathrm{N} \mathrm{m}^{-2}$ was incorporated in surface waters in summer (mid July-mid August). Their estimate for late summer and fall amounted to $50 \mathrm{mmol} \mathrm{N} \mathrm{m}{ }^{-2}$ (mid August-mid October), but Was- 


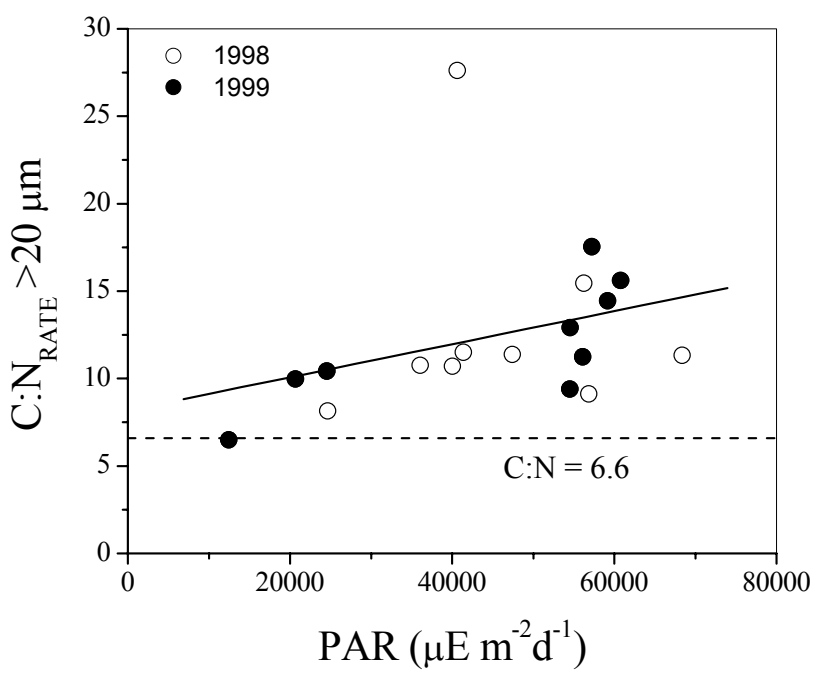

Fig. 7. Integrated $\mathrm{C}: \mathrm{N}_{\mathrm{RATE}}>20 \mu \mathrm{m}$ as a function of daily integrated PAR in 1998 (open circles) and 1999 (closed circles). The dashed line is the Redfield relationship and the solid line is the linear regression; $y=0.000095( \pm 0.000069) \cdot x+8.18( \pm 3.31), n=18$, $\mathrm{R}=0.322, \mathrm{P}=0.192$.

mund et al. (2001) did not include the early summer phase of the bloom of filamentous cyanobacteria. Assuming that the early onset of the bloom lasted about a month, our study may suggest that a significant amount of $\mathrm{N}_{2}$ fixation contributed to new production in $1998\left(15 \mathrm{mmol} \mathrm{N} \mathrm{m}^{-2}\right)$ and 1999 ( $33 \mathrm{mmol} \mathrm{N} \mathrm{m}^{-2}$ ). By including the early bloom, 12 $26 \%$ more $\mathrm{N}$ can be added to the annual estimate given by Wasmund et al. (2001), which brings the annual budget in the range of $140-158 \mathrm{mmol} \mathrm{N} \mathrm{m}^{-2} \mathrm{yr}^{-1}$. The between-station variability in both primary production and $\mathrm{N}_{2}$ fixation that appeared in this study greatly emphasizes the need for implementing spatial as well as temporal sampling strategies in ecological studies of the Baltic Sea.

4.2 Primary production and $\mathrm{N}_{2}$ fixation in filamentous cyanobacteria

We found that cells collected in the $>20 \mu \mathrm{m}$ fraction were predominantly filamentous cyanobacteria (Fig. 6) and the contribution of $\mathrm{N}_{2}$ fixation to new production in open waters of the Baltic Sea was almost entirely found in cells $>20 \mu \mathrm{m}$ (Table 3). Gallon et al. (2002) found that filamentous cyanobacteria incorporate $\mathrm{C}$ and $\mathrm{N}$ at ratios much higher than the Redfield ratio of 6.6 in surface water (Redfield et al., 1963). By applying these C:N incorporation ratios to our specific depths (C: $\mathrm{N}_{\text {RATE }}[0-7 \mathrm{~m}]=17.6 ;[7-14 \mathrm{~m}]=5.1$; Gallon et al., 2002) we calculated how much new $\mathrm{N}$ from $\mathrm{N}_{2}$ fixation did support the measured rates of primary production. Integrated rates of $\mathrm{N}_{2}$ fixation in filamentous cyanobacteria contributed an average of $73 \%$ in the 1998 transect (range 28$119 \%$ ) and $81 \%$ in 1999 (range 46-150\%) towards the mea- sured rates of primary production in cells $>20 \mu \mathrm{m}$. This may suggest that filamentous cyanobacteria were able to support their photosynthetic growth requirement with new $\mathrm{N}$ at some of the stations, while at other stations they were not able to complement their growth by diazotroph $\mathrm{N}$ at the days visited. The average integrated C: $\mathrm{N}_{\mathrm{RATE}}$ ratios in cells $>20 \mu \mathrm{m}$ in this study (Table 4) were almost two times higher than the Redfield ratio of 6.6 in both years but showed high variability in both years (C:N $N_{\text {RATE }}$ ranged between 7-28). Gallon et al. (2002) found a similar C:N $\mathrm{N}_{\text {RATE }}$ ratio to ours and noted a temporal uncoupling between $\mathrm{C}$ and $\mathrm{N}$ incorporation rates in the filamentous diazotrophs investigated over 3 diel cycles. In high light conditions, filamentous cyanobacteria do incorporate excess amounts of $\mathrm{C}$ as glucose, lipids and polyhydroxybutyrate storage products (Stal and Walsby, 1998). Loss of buoyancy results from excessive C-incorporation and carbohydrate ballasting (Ibelings et al., 1991) limiting the exposure of filamentous cyanobacteria to UV irradiance in the top layer of the water column. In our study integrated C: $N_{\text {RATE }}$ in cells $>20 \mu \mathrm{m}$ was frequently higher on days with high surface irradiance (Fig. 7) showing that measured rates of primary production and $\mathrm{N}_{2}$ fixation were at times out of phase. These rates were not reflected however, in C: $N_{\text {MASS }}$ of all particles combined or $>20 \mu \mathrm{m}$ (Table 3). Indeed, $\mathrm{C}: \mathrm{N}_{\text {MASS }}$ ratios were similar to the Redfield ratio suggesting that excess $\mathrm{C}$ incorporated was stored on a very short term basis $(<24 \mathrm{~h})$. Also a low cellular P content causes loss of buoyancy in filamentous cyanobacteria (Konopka et al., 1987; Klemer et al., 1995) and particles $>20 \mu \mathrm{m}$ had a low P content in our study (Table 4). Low P is commonly found in filamentous cyanobacteria in the Baltic Sea in summer (Larsson et al., 2001; Nausch et al., 2004).

Other studies in the Baltic Sea have found that diazotrophs can meet (Sörensen and Sahlsten, 1987) or even exceed (Stal and Walsby, 2000) their growth requirements for new $\mathrm{N}$ by $\mathrm{N}_{2}$ fixation. The biogeochemical estimates by Larsson et al. (2001), based on measurements of total nitrogen, also suggested that Baltic Sea cyanobacteria were able to assimilate more new $\mathrm{N}$ through $\mathrm{N}_{2}$ fixation, than what was needed to support their growth. The Gallon et al. (2002) study noted a discrepancy in the rates of $\mathrm{N}_{2}$ fixation determined by the acetylene reduction method (gross $\mathrm{N}_{2}$ fixation) and the ${ }^{15} \mathrm{~N}$ tracer method (net $\mathrm{N}_{2}$ fixation). They concluded that a significant amount of newly fixed $\mathrm{N}$ may have been released by the filamentous cyanobacteria (Gallon et al., 2002) and this was not being accounted for with the ${ }^{15} \mathrm{~N}$ tracer method used in this study. We found evidence of exudation of newly fixed $\mathrm{N}$ (see below) and this may be a reason for the discrepancy between our study and the gross estimates of $\mathrm{N}_{2}$ fixation mentioned above (Stal and Walsby, 2000; Sörensen and Sahlsten, 1987; Larsson et al., 2001). A crude comparison between these gross estimates from literature and our results based on the ${ }^{15} \mathrm{~N}$ method ( $73 \%$ and $81 \%$, see above), indicates that filamentous cyanobacteria may excrete as much as one third of newly fixed $\mathrm{N}$ during the course of a day. Stal et 
al. (2003) suggested that up to $80 \%$ of recently fixed $\mathrm{N}$ can at times be released over shorter periods of time in surface waters of the Baltic Sea. High C:NRATE ratios in filamentous cyanobacteria may also be caused by uptake of other sources of N (Sörensson and Sahlsten, 1987). Mulholland et al. (2004) found rapid uptake of previously released $\mathrm{NH}_{4}$ and DON in their cultures of Trichodesmium. Evans et al. (2000) found that nitrogenase activity in filamentous cyanobacteria decreased over the course of a day in the Baltic Sea and we suggest that this can be attributed to simultaneous uptake of regenerated $\mathrm{N}$. Therefore, the exceedingly high C: $\mathrm{N}_{\mathrm{RATE}}$ ratios found in this study may be as a consequence of both excess $\mathrm{C}$ incorporation as well as release of newly fixed $\mathrm{N}$ and regenerated $\mathrm{N}$ incorporation.

\subsection{Diazotroph release of DON and single cell $\mathrm{N}_{2}$ fixation}

Cells $<5 \mu \mathrm{m}$ incorporated 9\% in 1998 and 15\% in 1999 of total $\mathrm{N}_{2}$ fixation and in the pre-incubation size fractionation experiments the $<5 \mu \mathrm{m}$ fraction showed no detectable rates of $\mathrm{N}_{2}$ fixation in this study. Therefore, the observed ${ }^{15} \mathrm{~N}$ enrichment in cells $<5 \mu \mathrm{m}$ may have resulted from recent $\mathrm{N}_{2}$ fixation excreted as DON or $\mathrm{NH}_{4}$ and incorporated by nondiazotroph phytoplankton. Cyanobacteria are known to release nitrogenous material as DON (Flynn and Gallon, 1990; Glibert and Bronk, 1994) and $\mathrm{NH}_{4}$ (Mulholland and Capone, 2001) at times of excess $\mathrm{N}_{2}$ fixation relative to cellular synthesis (Gallon et al., 2002). Our study confirms the findings of Ohlendieck et al. (2000), who suggested that newly fixed $\mathrm{N}$ was transferred from filamentous cyanobacteria to smaller plankton. In their study, an increase in abundance of Synechococcus sp. was observed between cruises and over the course of a month, and this co-occurred with a developing bloom of filamentous cyanobacteria in the central Baltic Sea in 1995. Ohlendieck et al. (2000) suggested that the observed increase in biomass of the non-diazotroph cyanobacteria may have been fuelled by newly excreted DON from the larger filamentous diazotrophs. Pico-cyanobacteria are strongly Nlimited in the Baltic Sea and may benefit from diazotroph cyanobacteria as a nutrient source, since they show similar temporal and spatial distribution (Stal et al., 2003). The release of $\mathrm{N}$ by filamentous cyanobacteria represents an important and significant way of making new $\mathrm{N}$ available for the pelagic food-web at the early stage of cyanobacterial blooms in the Baltic Sea.

By monitoring total $\mathrm{N}$ in surface waters of the Baltic Sea in summer, Larsson et al. (2001) estimated the annual new production by $\mathrm{N}_{2}$ fixation and found a sizeable amount of $\mathrm{N}$ that could not be attributed to their estimates of filamentous cyanobacteria biomass (determined from cell counts). Larsson et al. (2001) concluded that the $\mathrm{N}$ that could not be accounted for may have been generated by DON excretion from filamentous cyanobacteria, or generated by other diazotrophs that were not investigated in their study. $\mathrm{N}_{2}$ fixation by single cell cyanobacteria represents another source of newly fixed $\mathrm{N}$ to the pelagic food-web in early summer. In our study we found $\mathrm{N}_{2}$ fixation in the pre-screened cells $<20 \mu \mathrm{m}$ (Table 2). Since the group specific pigment echinenone was not found in size fractions $<20 \mu \mathrm{m}$, we assume that this size fraction did not contain any significant amounts of filamentous cyanobacteria. Wasmund et al. (2001) also detected $\mathrm{N}_{2}$ fixation in the smaller size fractions of Baltic Sea phytoplankton. They estimated that cells $<10 \mu \mathrm{m}$ contributed $43 \%$ of total $\mathrm{N}_{2}$ fixation in the upper $20 \mathrm{~m}$ of the water column (Wasmund et al., 2001) and suggested that this was caused by non-heterocystous, coccoid cyanobacteria. Recent studies have also demonstrated that significant amounts of active single cell diazotrophs are found in temperate regions of the northern Pacific (Zehr et al., 2001; Montoya et al., 2004). Since we did not detect any significant rates of $\mathrm{N}_{2}$ fixation in cells $<5 \mu \mathrm{m}$ in our daylight incubations, we conclude that cells between 5-20 $\mu \mathrm{m}$ (or aggregations of smaller sized single cell cyanobacteria) in the Baltic Sea in early summer may at times use $\mathrm{N}_{2}$ fixation to support their nutrient requirements.

\subsection{The importance of $\mathrm{N}_{2}$ fixation to total primary produc- tivity}

Assuming the same C: $\mathrm{N}_{\mathrm{RATE}}$ assimilation ratios as above (Gallon et al., 2002), integrated rates of total $\mathrm{N}_{2}$ fixation contributed 13\% in 1998 (range 4-24\%) and 18\% in 1999 (range $2-45 \%$ ) to total primary production. In recent years, a wide range in C: $N_{R A T E}$ ratios has emerged from Baltic Sea studies. By using the ${ }^{15} \mathrm{~N}$-tracer method, Wasmund et al. (2001) found a C: $\mathrm{N}_{\mathrm{RATE}}$ of 6.8 at the height of the bloom of filamentous cyanobacteria in August 1997. During other stages of the bloom however, molar C: $\mathrm{N}_{\mathrm{RATE}}$ approached 20 to $>100$ and in August the year after, only $17 \%$ of the average $\mathrm{N}$ demand could be met by $\mathrm{N}_{2}$ fixation (Wasmund et al., 2001). Studies taking into account gross $\mathrm{N}_{2}$ fixation on the other hand, e.g. acetylene reduction by Stal and Walsby (2000) and total $\mathrm{N}$ biogeochemistry by Larsson et al. (2001), have generally measured a higher contribution $(>50 \%)$ to new production. This discrepancy can to a large extent be attributed to $\mathrm{N}$ excretion (see Gallon et al., 2002) that is not being accounted for in $\mathrm{N}_{2}$ fixation estimates using the ${ }^{15} \mathrm{~N}$-tracer method. Sörensson and Sahlsten (1987) however, measured $\mathrm{N}_{2}$ fixation by the acetylene reduction method and found that $\mathrm{N}_{2}$ fixation contributed only $16 \%$ of the total $\mathrm{N}$ utilized by the phytoplankton community at station BY31 (stations 8 in 1998 and 9 in 1999 in this study). The low contribution to new production by $\mathrm{N}_{2}$ fixation in the Sörensson and Sahlsten (1987) study may suggest that other nutrient sources (such as regenerated $\mathrm{N}$ ) were utilized by the phytoplankton community (including the diazotroph cyanobacteria). The Sörensson and Sahlsten (1987) study took place in late summer during the last stages of a cyanobacterial bloom. At that time we can assume that there was a closely coupled foodweb dominated by regenerated production with ammonium 
as one of the major sources of $\mathrm{N}$. In contrast, our study took place at the beginning of the cyanobacterial growth season with a plankton community still attuned towards new production and relatively low levels of ammonium. We found that 9 and $15 \%$ of the total rate of $\mathrm{N}_{2}$ fixation (dominated by filamentous cyanobacteria), was incorporated by cells $<5 \mu \mathrm{m}$ in early summer (Fig. 5). This is almost a factor of ten less than what Sahlsten and Sörensson (1989) found during a declining cyanobacterial bloom in the same area $(71-93 \%$ of total N). In our study we found relatively low concentrations of ammonium (median conc. $0.05 \mu \mathrm{M}$ ) in 1998 and the median concentration of ammonium in 1999 was almost twice as high (approx. 0.1 $\mu \mathrm{M}$ ). The higher median values of ammonium in surface waters during the 1999 transect (Fig. 3) also coincided with higher rates of $\mathrm{N}_{2}$ fixation during that transect and a higher level of ${ }^{15} \mathrm{~N}$-enrichment in cells $<5 \mu \mathrm{m}$ (Fig. 5). The diel increase in ammonium concentrations reported by Stal et al. (2003) for the 1999 transect may be as a result of enzymatic regeneration of newly released DON or release of $\mathrm{NH}_{4}$ and hence, the larger filamentous diazotrophs may have contributed new $\mathrm{N}$ to the pool of regenerated nutrients. Surface waters of the Baltic Sea in summer are characterized by a low N:P nutrient ratio and we can assume that regenerated nutrients are readily utilized by the non-diazotroph components of the phytoplankton community. Therefore, we concur with Larsson et al. (2001) in that $\mathrm{N}_{2}$ fixation may sustain a considerable fraction of net community production in the Baltic Sea in summer. Rolff (2000) also demonstrated that the effect of $\mathrm{N}_{2}$ fixation (trophic $\delta^{15} \mathrm{~N}$ enrichment) was found in all size fractions of phytoplankton in the Baltic Sea in late summer. Hence, $\mathrm{N}_{2}$ fixation in summer may contribute significantly to new as well as regenerated production in surface waters of the Baltic Sea.

\section{Summary}

This study shows that $\mathrm{N}_{2}$ fixation by filamentous cyanobacteria may provide a significant input to new production in the surface waters of the Baltic Sea in early summer. Disproportionate amounts of $\mathrm{C}$ are at times incorporated relative to $\mathrm{N}$ in filamentous cyanobacteria. Since the C: $\mathrm{N}_{\text {MASS }}$ is fairly constant and similar to the Redfield ratio, we assume that excess $\mathrm{C}$ is not stored in cells over longer periods of time and possibly used within the course of a day. Filamentous cyanobacteria and non-diazotroph phytoplankton may also utilize significant amounts of regenerated N. Even though the phytoplankton community is dominated by nondiazotroph organisms in the Baltic Sea, a small fraction of single cell diazotrophs may at times contribute significantly towards new production. Total rates of $\mathrm{N}_{2}$ fixation, measured by the ${ }^{15} \mathrm{~N}$ tracer method, contribute only a minor portion of new $\mathrm{N}$ to the phytoplankton community in summer. DON release from filamentous diazotroph cyanobacteria however, may contribute significantly towards the utilization of regen- erated $\mathrm{N}$ by the non-diazotroph community of phytoplankton.

Acknowledgements. We thank the Captain and crew on $\mathrm{R} / \mathrm{V}$ A. v. Humboldt and $\mathrm{R} / \mathrm{V}$ Valdivia for help and support during numerous seawater collections. We are indebted to $\mathrm{K}$. von Bröckel (Chief Scientist) for facilitating two excellent summer cruises to the Baltic proper. F. Lipschultz (BBSR) did the analysis of the ${ }^{15} \mathrm{~N}$-samples. Post cruise data processing and planning of this paper was supported by ESF-CYANOFIX. This is an ELOISE publication supported by the European Commission (the Environment Programme) contract number EV5V-CT94-0404 to the BASIC project.

Edited by: J. Middelburg

\section{References}

Barlow, R. G., Cummings, D. G., and Gibb, S. W.: Improved resolution of mono- and divinyl chlorophylls $a$ and $b$ and zeaxanthin and lutein in phytoplankton extracts using reverse phase C-8 HPLC, Mar. Ecol. Prog. Ser., 161, 303-307, 1997.

Derenbach, J.: Zur Homogenisation des Phytoplanktons für die Chlorophyllbestimmung, Kieler Meeresforschungen, XXV, 166$171,1969$.

Dugdale, R. C. and Goering, J. J.: Uptake of new and regenerated forms of nitrogen in primary productivity, Limnol. Oceanogr., 12, 196-206, 1967.

Evans, A. M., Gallon, J. R., Jones, A., Staal, M., Stal, L. J., Villbrandt, M., and Walton, T. J.: Nitrogen fixation by Baltic cyanobacteria is adapted to the prevailing photon flux density, New Phytol., 147, 285-297, 2000.

Fitzwater, S. E., Kramer, G. A., and Martin, J. H.: Metal contamination and its effects on primary production measurements, Limnol. Oceanog., 27, 544-551, 1982.

Flynn, K. J. and Gallon, J. R.: Changes in intracellular and extracellular $\alpha$-aminoacids in Gloeotheke during $\mathrm{N}_{2}$ fixation and following addition of ammonium, Arch. Microbiol., 153, 574-579, 1990.

Gallon, J. R., Albertano, P., Bergman, B., von Bröckel, K., Canini, A., Congresti, R., Evans, A. M., Fritsche, P., Gundersen, K., te Lintel Hekkert, S., Jones, D. A., Meyerhöfer, M., Nachtigall, K., Ohlendieck, U., Orcutt, K. M., Repka, S., Sivonen, K., Staal, M., and Stal, L. J.: $\mathrm{N}_{2}$ fixation and primary production are uncoupled in a developing cyanobacterial bloom in the Baltic Sea, Limnol. Oceanogr., 47, 1514-1521, 2002.

Glibert, P. M. and Bronk, D. A.: Release of dissolved organic nitrogen by marine diazitrophic cyanobacteria, Trichodesmium spp., Appl. Environ. Microbiol., 60, 3996-4000, 1994.

Grasshoff, K., Ehrhardt, M., and Kremling, K.: Methods of seawater analysis, Verlag Chemie, Weinheim, 1983.

Gundersen, K.: The distribution and biological transformations of nitrogen in the Baltic Sea, Mar. Pollut. Bull., 12, 199-205, 1981.

Ibelings, B. W., Mur, L. R., and Walsby, A. E.: Diurnal changes in buoyancy and vertical distribution in populations of Microcystis in two shallow lakes, J. Plankton Res., 13, 419-436, 1991.

Kahru, M., Horstmann, U., and Rud, O.: Satellite detection of increased cyanobacteria blooms in the Baltic Sea: Natural fluctuation or ecosystem change?, Ambio, 23, 469-72, 1994. 
Klemer, A. R., Hendzel, L. L., Findlay, D. L., Hedin, R. A., Mageau, M. T., and Konopka, A.: Carbon availability and the pattern of cyanobacterial dominance in enriched low-carbon lakes, J. Phycol., 31, 735-744, 1995.

Konopka, A., Kromkamp, J., and Mur, L. R.: Regulation of gas vesicle content and buoyancy in light- or phosphate-limited cultures of Aphanizomenon flos-aquae (Cyanophyta), J. Phycol., 23, 70-78, 1987.

Kuparinen, J. Leppänen, J.-M., Sarvala, J., Sundberg, A., and Vistanen, A.: Production and utilizzation of organic matter in Baltic ecosystem off Tvärminne, southwest coast of Finland, Rapp. P.V. Reun.-Cons. Int. Explor. Mer., 183, 180-192, 1984.

Larsson, U., Hajdu, S., Walve, J., and Elmgren, R.: Baltic nitrogen fixation estimated from the summer increase in upper mixed layer total nitrogen, Limnol. Oceanogr., 46, 811-20, 2001.

Leppänen, J.-M., Niemi, Å., and Rinne, I.: Nitrogen fixation of cyanobacteria (blue-green algae) and the nitrogen cycle of the Baltic Sea, Symbiosis, 6, 181-194, 1988.

Lindahl, G., Wallström, K., and Brattberg, G.: Short-term variability in nitrogen fixation in a coastal area of the northern Baltic, Arch. Hydrobiol., 98, 88-100, 1980.

Mackey, M. D., Mackey, D. J., Higgins, H. W., and Wright, S. W.: CHEMTAX- a program for estimating class abundances from chemical markers: application to HPLC measurements of phytoplankton, Mar. Ecol. Prog. Ser., 144, 265-283, 1996.

Montoya, J. P., Voss, M., Kähler, P., and Capone, D. G.: A simple, high-precision, high-sensitivity tracer assay for $\mathrm{N}_{2}$ fixation, Appl. Environ. Microbiol., 62, 986-993, 1996.

Montoya, J. P., Holl, C. M., Zehr, J. P., Hansen, A., Villareal, T. A., and Capone, D. G.: High rates of $\mathrm{N}_{2}$ fixation by unicellular diazotrophs in the oligotrophic Pacific Ocean, Nature, 430, 1027-1031, 2004.

Mulholland, M. R. and Capone, D. G.: Stoichiometry of nitrogen utilization in cultured populations of Trichodesmium IMS101: Implications for growth, Limnol. Oceanogr., 46, 436-443, 2001.

Mulholland, M. R., Bronk, D. A., and Capone, D. G.: Dinitrogen fixation and release of ammonium and dissolved organic nitrogen by Trichodesmium IMS101, Aquat. Microb. Ecol., 37, 85-94, 2004.

Nausch, M., Nausch, G., and Wasmund, N.: Phosphorus dynamics during the transition from nitrogen to phosphate limitation in the central Baltic Sea, Mar. Ecol. Prog. Ser., 266, 15-25, 2004.

Niemistö, L., Rinne, I., Melvasalo, T., and Niemi, Å.: Blue-green algae and their nitrogen fixation in the Baltic Sea in 1980, 1982, and 1984, Meri, 17, 3-59, 1989.

Ohlendieck, U., Stuhr, A., and Siegmund, H.: Nitrogen fixation by diazotrophic cyanobacteria in the Baltic Sea and transfer of the newly fixed nitrogen to picoplankton organisms, J. Mar. Syst., 25, 213-219, 2000.

Paerl, H. W.: Transfer of $\mathrm{N}_{2}$ and $\mathrm{CO}_{2}$ fixation products from $A n$ abaena oscillarioides to accociated bacteria during inorganic carbon sufficiency and deficiency, J. Phycol., 20, 600-608, 1984.

Rahm, L., Jönsson, A., and Wulff, F.: Nitrogen fixation in the Baltic proper: an empirical study, J. Mar. Syst., 25, 239-48, 2000.
Redfield, A. C., Ketchum, B. H., and Richards, F. A.: The influence of organisms on the sea water, in: The sea, Vol. 2, edited by: Hill, M. N., General Edition Inter-science Publishers, London, pp. 26-77, 1963.

Rinne, I., Melvasalo, T., Niemi, Å., and Niemistö, L.: Nitrogen fixation by blue-green algae in the Baltic Sea, Kieler Meeresforsch. Sonderheft, 4, 178-187, 1978.

Rolff, C.: Seasonal variation in $\delta^{13} \mathrm{C}$ and $\delta^{15} \mathrm{~N}$ of size-fractionated plankton at a coastal station in the northern Baltic proper, Mar Ecol. Prog. Ser., 203, 47-65, 2000.

Sahlsten, E. and Sörensson, F.: Planktonic nitrogen transformations during a declining bloom in the Baltic Sea, J. Plankt. Res., 11, 1117-1128, 1989.

Schultz, S. and Kaiser, W.: Increasing trends in plankton variables in the Baltic Sea - a further sign of eutrophication?, Ophelia (Suppl.), 4, 249-257, 1986.

Solorzano, L. and Sharp, J. H.: Determination of total dissolved phosphorus and particulate phosphorus in natural waters, Limnol. Oceanogr., 25, 754-758, 1980.

Stal, L. J. and Walsby, A. E.: The daily integral of nitrogen fixation by planktonic cyanobacteria in the Baltic Sea, New Phytol., 139, 665-671, 1998.

Stal, L. J. and Walsby, A. E.: Photosynthesis and nitrogen fixation in a cyanobacterial bloom in the Baltic Sea, European J. Phycol., 35, 97-108, 2000.

Stal, L., Albertano, P., Bergman, B., Bröckel, K. v., Gallon, J., Hayes, P. K., Sivonen, K., and Walsby, A. E.: BASIC: Baltic Sea cyanobacteria. An investigation of the structure and dynamics of water blooms of cyanobacteria in the Baltic Sea - responses to a changing environment, Cont. Shelf Res., 23, 1695-1714, 2003.

Stoecker, D., Autio, R., Rintala, J.-M., and Kuosa, H.: Ectocellular enzyme activity associated with filamentous cyanobacteria, Aquat. Microbiol. Ecol., 40, 151-161, 2005.

Sörensson, F. and Sahlsten, E.: Nitrogen dynamics of a cyanobacteria bloom in the Baltic Sea: new versus regenerated production, Mar. Ecol. Prog. Ser., 37, 277-284, 1987.

Walsby, A., Hayes, P., and Boje, R.: The gas vesicles, buoyancy and vertical distribution of cyanobacteria in the Baltic Sea, Eur. J. Phycol., 30, 87-94, 1995.

Wasmund, N.: Occurrence of cyanobacterial blooms in the Baltic Sea in relation to environmental conditions, Int. Rev. Ges. Hydrobiol., 82, 169-184, 1997.

Wasmund, N., Voss, M., and Lochte, K.: Evidence of nitrogen fixation by non-heterocystous cyanobacteria in the Baltic Sea and re-calculation of a budget of nitrogen fixation, Mar. Ecol. Prog. Ser., 214, 1-14, 2001.

Weiss, R. F.: The solubility of nitrogen, oxygen, and argon in seawater, Deep-Sea Res., 17, 721-735, 1970.

Zehr, J. R., Waterbury, J. B., Turner, P. J., Montoya, J. P., Omoregie, E., Steward, G. F., Hansen, A., and Karl, D. M.: Unicellular cyanobacteria fix $\mathrm{N}_{2}$ in the subtropical North Pacific Ocean, Nature, 412, 635-638, 2001. 